\title{
Preservice Teachers' Perceptions of Immigrants and Possibilities of Transformative Pedagogy: Recommendations for a Praxis of "Critical Aesthetics"
}

\author{
Morna McDermott \\ Towson University \\ U. S. A. \\ Nancy Rankie Shelton \\ University of Maryland Baltimore County \\ U. S. A. \\ Stephen G. Mogge \\ Towson University \\ U. S. A.
}

To address anti-immigration sentiments revealed by preservice educators, the authors conducted a workshop using a "critical-aesthetic praxis." The purpose of the workshop was to create a praxis (Freire, 1970;1998) of critical aesthetics (Carey, 1998) in which preservice teachers engaged in a series of aesthetically grounded experiences aimed at revealing and disorienting their previously conceived notions about immigration. The workshop lay the groundwork for a re-orientation of understanding based on perspectives of the "the Other" and builds a transformative curriculum in teacher education programs. Such practices must become more integral facets of teacher preparation programs to promote an anti-racist pedagogy.

Theoretical Framework Constructing the Workshop

Data Collection and Analysis Findings

Discussion

References

Appendix 1

Critical contemporary issues in U.S. education must include conversations about immigration policies and practices that have shaped our past, define our present, and will enrich our collective future. According to the most current data available from the U.S. Census Bureau, foreign-born populations in the United States have reached 38.5 million people, or 12.5 percent of the total U.S. population. In addition, $45.5 \%$ of these citizens were born in Latin America, and of that population Central America accounted for $70.5 \%$ of the foreign-born Latin American population and more than one-third (38\%) of the total foreign-born U.S. population (U.S. Census Bureau, 2011). The enrollment of English Language Learners in U.S. schools more than doubled, rising from 2,030,451 students to 5,074,572 between 1989-1990 and 2005-2006 (National Clearinghouse for 
English Language Acquisition, 2008). Given these demographic changes, it is clear that today's preservice teachers must be prepared to succeed in culturally and linguistically complex classrooms (Ball, Skerrett, \& Martinez, 2011). This requires that teachers be aware of and responsive to the heritage and cultural practices of students in the schools where they will teach. However, the new generation of future U.S. teachers has grown up amidst conflicting messages regarding the place for immigrants and their children in the United States. Conflicts over immigration policy continue to rage at federal and state levels as well as in the media. Today's preservice teachers have seen the passing of California's Proposition 187 but also the subsequent elimination of most of its provisions and the rise of state-level Latino politicians in the aftermath (Tichenor, 2002; Zolberg, 2006). More recently, the states of Arizona, Georgia, and Alabama have passed highly controversial anti-immigrant laws for which they received widespread condemnation while several provisions of the new laws have been questioned on constitutional grounds (Wightman, 2010). During this era, border enforcement proponents, but also immigrant rights advocates, have demonstrated publicly and elevated their rhetoric to maximize media exposure and influence public opinion.

A 2006 Pew Research Center survey reveals just how conflicted public opinion is regarding immigration policy and the presence of immigrants in the United States (Pew Research Center, 2006). In the survey, 40\% of respondents indicate that legal immigration levels should decrease; $37 \%$ indicate that levels should be kept the same, and $17 \%$ favor an increase (p. 2). $53 \%$ of respondents indicate that illegal immigrants should be required to go home while $40 \%$ indicated they should be allowed to stay (p. 1). In order to reduce illegal immigration, $49 \%$ of respondents favored penalizing employers while $42 \%$ preferred the increase of border patrol or the building of more fences (p. 2). Amidst the public debate over how the United States will assert its future identity with respect to newcomers, education policy has generally moved in the direction of English-only instruction. Despite the abundant research evidence that supports native language literacy development and instruction as an effective agent for promoting English language literacy development (August \& Shanahan, 2008; Krashen \& McField, 2006), the states of California, Arizona, and Massachusetts have adopted polices to eliminate bilingual education programming in favor of English-only or immersion models of instruction. The 2001 reauthorization of the Elementary and Secondary Education Act (ESEA) eliminated the word bilingual from the law and from any government offices associated with the law. Further, it promoted an English-only policy that subjects English learners to the same testing regimen that all children endure under No Child Left Behind (Garcia \& Wiese, 2009). Policy makers have simply ignored the research that makes clear accepted developmental stages and timeframes for second language development (Thomas \& Collier, 1997) and the decades of evidence that supports heritage language preservation and bilingual/biliteracy education (August \& Shanahan, 2008; Bialystock, 1997; Cummins, 1993; Hakuta, 1986) in favor of what appears to be a more palatable policy based on public opinion. Wiley (2005) identifies several popular myths that underlie these 
language education policies. These include the belief that the United States is a monolingual nation; that English is threatened; that English is the only literacy worth knowing; that immigrants are not eager to learn English; that language minority adults favor English-only instruction for their children; and that Englishonly immersion is the best choice for language minority children's success.

Today's preservice teachers have come of age and are preparing to enter the teaching profession at a time of remarkable public discord regarding the $20 \%$ of our nation's school children who are born to immigrant parents (Valdez \& Callahan, 2011). These young adults are left to contend with opposing perspectives on immigration and a fundamental disconnect between language minority education research and public policy. In this environment, it is worth considering what perspectives they will bring and how teacher educators can prepare them for the experience. In response to these factors, a team of three university professors, each with a distinct scholarly background, came together and developed a workshop, hoping to address (through children's literature, artsbased pedagogy, and first-person immigrant narratives) the struggles, biases, and fears of preservice teachers.

\section{Theoretical Framework}

The purpose of the workshop was to develop and implement a praxis (Freire, 1970;1998) of critical aesthetics (Carey, 1998) in which preservice teachers were guided through a series of aesthetically grounded experiences aimed first at revealing and then at disorienting their previously conceived notions about immigration. The workshop then laid the groundwork for a reorientation of understanding based on perspectives of the "Other" and offered opportunities to build transformative curriculum in both teacher education programs and K-12 classrooms.

The "browning of immigration" over the last few decades parallels the rise of "tougher" immigration laws, illuminating the racist undercurrent to "manage" or control groups who have already historically been colonized in their native countries, as well as in the United States. The assumptions White teachers may have about immigrant students go hand in hand with underlying assumptions about the history of colonization and imperialism found in the textbooks and lessons that ground the K-12 educational experiences of many of these beginning teachers. As a result, White teachers may dis-associate their own immigrant histories from those of their current students (Reilly, 2011, p. xxxv). This leads to the "Othering" of immigrant children by way of situating the teachers' own immigrant stories in the unique context of American United States "history," where European ethnic groups made the gradual transition from being minority outcasts to becoming White and, therefore, normal (Ignatiev, 1995). This "history," saturated in a romantic narrative, grossly juxtaposes historic immigration accounts with current narratives in which adjectives such as illegal are nominalized in order to dehumanize those in search of a better life. 
In this study, we developed a framework we call "a critical-aesthetic praxis." Critical aesthetics has less to do with aesthetics as traditionally understood as an element of formal "high" art, such as that which hangs in museums, and draws instead from aesthetics of the imagination - what it is we hear, see, feel, and imagine as possible avenues for meaning making. Critical aesthetics draws largely from the works of hooks (1995), Carey (1998), Freire (1970; 1998), and Boal (1979; 1995; 2002). Examining aesthetics critically (Carey, 1998) is a way to subvert more conventional ways of thinking and provoke reflections of self (and society) in order to question the paradigms in which we operate. Carey argues for more critical forms of arts-based practices in education that move towards a praxis that "opens the knowledge process to the subjective qualities of lived experience that expand meaning beyond the reified, objective, decontextualized, pseudo-values predetermined and handed down by experts as the uncontested criteria for reality and truth" (p. 310). Ultimately, such re-examinations offer ways to alternatively represent different kinds of knowing, to include other dialogues, ideas, and voices outside the current mainstream of research paradigms.

Such an approach to aesthetics as a pedagogical tool is grounded on two premises: 1) that art (and our aesthetic value system) is context specific, thus emphasizing the "interaction of language, culture, and society" (Barret, as cited in Anderson \& Milbrandt, 1998, p. 15), 2) that creativity can de-center the notion of the individual in favor of critically collective and community-oriented ways of knowing the world, and 3) that art, like teaching, is never neutral. Using these three premises as a theoretical frame, our workshop series was centered around the body (through drama) the senses (through what we hear, see, smell, taste, and feel), and how we reorient our perspectives toward others by standing in "their shoes" (children's literature and immigrant narratives). When critically examined in the forums discussed here, such aesthetic sensibilities also become the sites for re-orienting our world views away from one of separation and Otherness and toward a sense of empathy and relatedness.

The methodology of our study as well as its content both aim at centering marginalized (or colonized) perspectives excluded as both methodology and content of traditional Western research. According to Tuhiwai-Smith (1999):

From an indigenous perspective Western research is more than just research that is located in a positivist tradition. It is research which brings to bear, on any study of indigenous peoples, a cultural orientation, a set of values, a different conceptualization of such things as time, space and subjectivity, different and competing theories of knowledge, highly specialized forms of language, and structures of power. (p. 42)

In keeping with the goals of an anti-colonial approach to teaching and inquiry, praxis (Freire, 1998) calls for reflective and reflexive action. In other words, it is not merely sufficient to articulate what is wrong with current preservice teacher assumptions about immigration. To guide educators toward a critical-aesthetic multicultural praxis we find it a necessary goal to encourage these preservice teachers to examine their own assumptions and beliefs, arguing 
that genuine dialogic reflection through the media of drama and literature might transform future classroom practices. Action must result in the transformation of our educational goals for immigrant children. Battiste (2011) states:

In the area of education, it is about reflecting on what the role of schooling has been, what barriers have excluded some voices from participation in schools, and what perceptions of others hold that prevent them from fully benefitting from what a transformative curriculum can offer. (p. xxiv)

\section{Constructing the Workshop}

This research began in 2006 as two teacher-educators struggled to adapt course content that would lead preservice teachers into critical self-examination related to social justice pedagogy (Banks, 2004; Christensen, 2009; Freire, 1970; 1998). Combining our professional experiences in drama and children's literature, we originally created a workshop that successfully brought rich discussion of how race, gender, and class are presented in elementary school settings (Rankie Shelton \& McDermott, 2010). However, with the increased negativity towards immigrants in the United States (i.e., organized marches across the country and congressional calls for increased border patrol) we shifted our workshop's focus in 2007 to how teachers' perceptions of immigration might influence their practice. Our interest in helping preservice teachers develop as critical educators required us to develop strategies that challenged them to question their existing perspectives and then to guide them to critically rethink how these ideologies would affect the students they will eventually teach.

In our initial workshops, preservice teachers identified immigrants in terms that are commonly associated with negative human experiences or unappealing personal attributes (Rankie Shelton, \& McDermott, 2008). This prompted our work in the direction of moving students towards further examination of their perceptions and knowledge of immigrants. Emerging from that data were key themes that included descriptive words from the participants describing immigration as "illegal, dirty, and smelly." Thus, we recognized that our original workshop's "re-examination" phase was too shallow. Our time was too brief and prevented deeper analysis of the participants' negative perceptions of immigrants.

Consequently, we redesigned the workshop, adding more written response and reflection, increasing the children's literature component, adding voices of adult immigrants, and recruiting a third teacher educator/researcher who had previously conducted teacher research studies with adult immigrants (Mogge, 2008). Adding this critical "first-person voiced" perspective brought real names and faces to the immigration experiences with which our workshop participants would become familiar. The data reported here includes the extended work undertaken in a 2.5 hour workshop with the preservice teachers. The workshop included six steps designed to move the participants through three stages: 1) initial understanding; 2) representation; and 3) re-examination. Figure 
1 (below) identifies the six steps undertaken in the workshop. A full description of the prompts and questions presented to the participants can be found in Appendix 1.

Figure 1. Six-Step Workshop

\begin{tabular}{|c|c|c|c|}
\hline $\left.\begin{array}{cc}\text { 1. Student Writing } \\
\text { - } & \text { Knowledge } \\
\text { - } & \text { Beliefs } \\
\text { - } & \text { Positives } \\
\text { - } & \text { Negatives }\end{array}\right\}$ & $\begin{array}{l}\text { 2. Initial } \\
\text { Perceptions of } \\
\text { Immigrants } \\
\text { - Look Like } \\
\text { - Smell Like } \\
\text { - Feel Like } \\
\text { - Taste Like } \\
\text { - Move Like }\end{array}$ & $\begin{array}{l}\text { 3. Children's } \\
\text { Literature } \\
\text { 4. Drama } \longrightarrow \\
\text { 5. Voices of } \\
\text { Immigrants }\end{array}$ & $\begin{array}{l}\text { 6. Reflections } \\
\text { - Immigrants' } \\
\text { Perspectives of } \\
\text { Students } \\
\text { - Negative } \\
\text { Stereotypes } \\
\text { - New Words } \\
\text { - Impact on } \\
\text { Beliefs }\end{array}$ \\
\hline
\end{tabular}

\section{Data Collection and Analysis}

While the workshops began in 2007 using just the drama and children's literature components, our findings (Rankie Shelton \& McDermott, 2011) from those five initial workshops suggested that the addition of more immigrantcentered personal experiences would be beneficial. We added immigrant voices in 2008 and held an additional four workshops with 78 preservice teachers representing the same demographics. In each of the four workshops there were between fifteen and twenty participants, ranging in ages between 18 and 40, with most of them between 18 and 25 . The groups were largely made up of White females in that age range. Less than 20 were people of color (we did not survey students regarding their preferred racial identities). Our research team, comprised of the three authors, are all Caucasian and between the ages of forty and sixty. One is male and two are female. We are all professors of teacher education at universities around the city of Baltimore, Maryland.

In order to conduct the workshops, authors of this study were invited as guest presenters into various graduate and undergraduate classes that deal with diversity in education, literacy theory and practice, and educational foundations. One of the three authors was the instructor for each of the classes, and the other two authors were brought in for the purposes of conducting the workshop as a class activity led by all three. All words written and spoken by the participants were kept anonymous in accordance with our university IRB agreement. 
Participation in the workshop was considered part of regular course expectations, though students were allowed the choice of whether or not they wished to have their information included in the study itself following the end of the actual workshop held. All course participants agreed to be participants of this study. Neither the in-class activities nor the write-ups they completed at the end of the workshop were evaluated using points or grades.

The workshop began with a brief two-minute writing prompt asking participants to share briefly their knowledge of immigration, after which they were asked to engage with their "senses" in a baseline understanding of what immigration feels like, sounds like, smells like, tastes like, and moves like. Participants were then exposed to a narrative from published children's literature (Kurtz, 2000) as well as excerpts of adult stories (Mogge, 2008) in which immigrants discuss their perceptions about living and striving to succeed amidst an intolerant atmosphere. Relying on drama and reader-response theory, participants were asked to embody and perform the characters and voices from the book for others in the class in order to deconstruct their perceptions of "others" (Copenhaver, 2000; Gaztambide-Fernandez, 2002; Laminack \& Wadsworth, 2006; Wolk, 2004).

Our research methodology draws from ethnographic and qualitative methods (Creswell, 1998; Emerson, Fretz, \& Shaw, 1995; Patton, 1980; Spradley, 1980) including note-taking by the authors during the sessions and recording what the participants said and did. After each session, the authors independently transcribed their notes and recorded more thoughts and evaluations of the workshop events and outcomes. The notes from all three authors were then compared to determine if there were re-occurring observations or themes. We coded our data, identifying patterns in the students' responses, sculptures, and skits. We then grouped the codes into re-occurring themes. Data collection also included all response artifacts produced during and after the workshops, such as lists generated on large poster paper. The authors independently reviewed all of the data collected during the workshops (the initial sense lists, the written responses, and final workshop evaluations) and compared their individual findings, looking for shared generalities and recurring issues, themes, or patterns. Analysis of the data suggests that the series of activities moved our students through three phases in their knowing: 1) initial understanding, 2) representation, and 3) re-examination.

Working from the lenses of social constructionism (Burr, 2003) and critical pedagogy (Freire, 1998), researchers analyzed all data sources for evidence of negotiated meanings of terms and concepts as well as how visual representations opened dialogue for new and contested world views. We also engaged with arts-based methodologies similar to those used in previous workshops (Rankie Shelton \& McDermott, 2011) in which the workshop leaders infused both ethnographic methodologies and arts-based processes as a form of methodology and data analysis. As such, the study focused on a "context for discovery" rather than a "context for justification" (Harding, in Leavy, 2009, p.8). 
Thus, findings were predicated on a methodology grounded in seeking new understandings rather than affirming predetermined theories.

\section{Findings}

Using various data sources from the 78 participants (12-25 in each of the four sessions) that included their two-minute beginning write-ups, the sensory lists, discussion of the children's book, the drama activities, and finally the firstperson immigrant voices, each of the steps or stages of this workshop were layered intentionally to gradually move participants from what they thought they "knew" in a distanced or disembodied stance toward a sense-based embodied perspective (Worthman, 2002). This required them to articulate first their own perceptions, and then more radically shift into the lived experience of the "Other," thus transitioning their own positionality. The author/researchers collectively agreed to define "negative" data as words or dramatic representations that cast immigration or immigrant persons in a negative light (i.e., having deleterious effects on "American" communities such as "stealing jobs," possessing negative attributes such as being "smelly" or possessing negative culturally-bound stereotypes such as "Mexicans are lazy"). Conversely, positive terms or representations were defined as those that cast immigrant persons or immigration experiences in a light which was respectful (i.e., "hard working"), sympathetic/empathetic (i.e., "scary leaving home"), or acknowledged positive contributions made by immigrants.

\section{Step 1: Student Writing: Starting with What They "Know"}

In step 1 participants were asked to write brief (two-minute) write-ups guided by questions around what they knew and believed about immigration and what they considered positive and negative about immigration. The participants' individual written responses at the beginning of the workshops were more negative than positive. Though the preservice teachers were directly asked to record what they knew to be positive about immigration policy, there were far fewer positive responses than negative ones. Out of 78 participants, 40 responses to these questions were negative. Thirty participants made negative comments about immigrants to the United States and 10 more made additional statements about the need to improve U.S. immigration policy. Collectively, only 23 positive statements about immigration were recorded. Additionally, positive words were mostly associated with cultural contributions such as food, dance, and dress. Further analysis of the positive statements revealed that 16 of the participants recognized distinct benefits for immigrating to the United States but only seven recognized the benefits immigrants bring to those of us already living in the United States. 
This initial data reflects the general attitudinal climate found in 2006 by the Pew Research Center, which reported that $52 \%$ of survey respondents believed that immigrants are a burden because they take jobs while $41 \%$ believed that they strengthen the United States with hard work and talents (p. 1).

\section{Step 2: Initial Impressions of Immigrants: Working with the Senses}

When asked for terms about what immigration looks like, smells like, sounds like, and tastes like, participants most frequently identified what were to them unappealing qualities, such as "the smell of grass cuttings." Forty-eight negative sensory descriptions of immigration were uttered, with several terms repeated by groups and within the same group for different sensory lists. The most frequent term used was "dirty." Also, "illegal, body odor, loud," and "sweaty" were used more than once to describe immigration. Descriptions of inconveniences such as "long lines" and "20 car pile-ups" led the participants into discussions of how their lives were disturbed by the intrusion of "others" who are "sweaty" and associated with "grimy smoke-stacks." Granted they may have been playing on images of immigrants coming to the Unites States during the Industrial Revolution, with recollections of The Jungle (Sinclair, 1906) as are often represented in popular media. However, the evidence of so few supportive, positive, or empathetic references in their lists simply suggests how entrenched their association of poor working conditions is with immigrants as people. In every workshop session, individuals in groups made shame-laden disclaimers that what they were about to say "would sound really bad." These disclaimers were usually followed by nervous laughter from their group. Other groups resisted sharing everything on their lists because of the possible guilt they felt from reading the words aloud. They often self-identified their statement as being "bad" or negative, in their own opinions, even though they went forth to proclaim them rather than demonstrating empathetic stances towards individuals in tenuous working or living conditions. The participant feedback suggested that immigrant people embody these negative attributes; the two become one, as one's immigrant status necessarily means she is smelly or dirty or causes crowding and deserving of blame for the attributed condition.

Additionally, most references to immigrants of various Latino decent(s) were commonly just labeled as "Mexican." Though the participants identified about 15 benefits of immigration for the immigrants themselves (e.g., new opportunities), they identified only eight for how immigration positively impacts U.S. society as a whole. For example, smell was often negatively associated with "ethnic foods" and aligned with terms like "stinky," "smelly," and "curry." Reference to food was the largest of all coded categories, traversing the sensory category prompts of taste, smell, and even sound (i.e., "Ching chang chong" in Chinatown). We believe that the negative association towards immigrant foods as being "intrusive" to the senses symbolizes workshop participants' underlying beliefs that immigrants are "intrusive" in "American" society. They are perceived as "exotic" or "different than." 
As authors of this article, we recognize that many references to immigration, which we collectively defined as negative in our praxis, may have been in part due to the nature of the exercise itself and that many responses may not have been the personally held beliefs of the participants but their referencing of social and cultural stereotypes they see in mainstream media. The use of the drama activity paired with the senses activity completed earlier in the workshop helped the authors in "drawing out" or "going within" the personal experiences of the participants themselves and then layering the data from each activity upon the other-seeking locations of similarity or disruption between naming social stereotypes and the personal absorption of anti-immigrant sensibilities based on personal life experience.

\section{Step 3: Children's Book}

The children's book Far Away Home (Kurtz, 2000) provoked many participants to also "see" immigration for the first time through the eyes of a child, rendering their senses closer to those of the protagonist. The book was selected deliberately as a positive story of immigration-one that touches on the loss of family and the ebullient shifts in identity felt by many immigrants-through the lens of a daughter wondering about what life was like for her father in Ethiopia. Through the narrative she imagines what his childhood was like, recognizing how dramatically different it was from her own. In the story the father must leave to go back to Ethiopia for a while because his own mother is ill and he must go visit her. The daughter's curiosity mingles with the subtle anxiety of knowing her father must go away for a while. With soft, watercolor illustrations and heartfelt conversations between father and daughter that draw the readers in and convey a "success" story of immigration, it is clear from the images and words that this family has acquired emotional, social, and economic well-being in America. One participant reflected:

"Far Away Home was a touching book. It hit home by touching on family life and the importance of a father's influence."

This text played a strong counter-narrative to the first workshop activity, in which most sense-based associations with immigration were cast as negative, and pulled the participants into the immigrant experience in a more empathetic way.

\section{Step 4: Drama Engaging with Theater of the Oppressed (TOP)}

In this section of the workshop, we drew on Kumashiro's (2000) analysis of the four primary approaches to anti-oppressive education: Education for the Other, Education about the Other, Education that is Critical of Privileging and Othering, and Education that Changes Students and Society (pp. 25 - 53). Our aim was to use the dialogic strategies of Theater of the Oppressed to invite each 
participant to embody their interpretations of the immigrant experience as they manifest in our individual psyches and in our social discourse. Participants examined how movement, positioning, and dialogue can affect relationships and challenge oppressive systems. Boal (1995) writes that "Theater or theatricality allows man (sic) to observe himself in action, in activity. The self-knowledge allows him to imagine variations of his action, to study alternatives" (p.13). This theater and pedagogical forum "result(s) (in) a pooling of knowledge, tactics and experience and (is) at the same time what Boal calls "a rehearsal for reality"' (Jackson, as cited in Boal, 2002, p. xxi).

Initially, we were hesitant to use TOP techniques (Boal, 1979; 1995; 2002) with a group of participants who by and large represented the dominant Eurocentric norm. We questioned their possible effectiveness, wondering "What stories of oppression could they possibly share?" and "What experiences could they possibly re-enact so as to empower themselves, since they represent the dominant and often oppressive 'norm' themselves?" We decided to use TOP techniques instead to draw from our participants their own stories, which often began with stereotypes and negative associations with immigration. According to Boal (1995), Image Theater (the first TOP technique we used) is "designed to uncover essential truths about societies and cultures without resorting to spoken language" (p. xix). Although the dramatic tableaux often encouraged participants toward empathetic viewpoints, it may be because we offered them key words to frame their tableaux, such as home or isolation, which were linked to the themes of Far Away Home that would lead them in that direction.

Following Image Theater, we asked participants in small groups to tell personal stories of experiences with immigration using Forum Theater. These stories ranged from their own personal and direct encounters with immigrants, to situations involving immigrants they had observed from a distance, to immigrant stories told about their own family's history. These stories were turned into Forum Theater skits. Forum Theater is "a theatrical game in which a problem is shown in an unsolved form, to which the audience, spect-actors, is invited to suggest and enact solutions" (Boal, 1995, p. xxi). However, when participants were asked to tell stories about immigration, they were most often negative or derogatory. The most common "theme" of the stories told involved restaurant workers who did not speak English. Also included was a skit about a young female being sexually harassed by lawn care workers, while another retold the story of one participant's car being rear-ended by a van from which dozens of "Mexicans" (sic) poured out and ran off.

Following each skit, we briefly discussed with the participants "what happened" and included questions such as "Who has the power in this situation?" and "What do you suppose the immigrant in this story is thinking or feeling right now?" Participants were asked to playback the scene and transform the power dynamics within the situation in ways that were intended to empower the immigrant in the story. Through the use of "playback" (Boal, 1995) we redirected the conversation toward critical reflections about power, privilege, and supremacy and then re-enacted scenes from the imagined perspective of the 
"Other." Through drama, the participants could stand back from their own complicity in the power dynamics, and from this distance take a more critical examination of the roles they consciously or unconsciously play in reinforcing relationships of stereotypes and supremacy. One participant wrote in her final reflection:

"The scene about the eight year old girl being asked to sit in the corridor at school was shocking. Parents entrust their children to teachers and this teacher abused her power. The forum theater and the image theater were both useful tools."

Another wrote:

[The most powerful for me was] "when we all got to share our personal experience with immigrants. I was able to see just how big a part they are in our lives."

\section{Step 5: Immigrant Voices}

As discussed earlier, the third member of our workshop/research team had previously conducted a two-year teacher research project with young adult immigrants (Mogge, 2008). This project focused on these students' development of English literacy within the context of their work as community leaders focusing on local issues like affordable housing and national issues like the welfare and immigration reforms of the late 1990s. These students wrote extensively about their lives and ambitions. Excerpts from these students' writing were used during the workshop. Two of these are below:

The dream of each hispanic is to come to the United States to verify whether or not all those wonderful things they saw in the movies are true. In their imagination they want to prove their chances in this country. They believe they be accepted in the United States and, maybe enjoy those beautiful places like the American people do. But the surprise come when [immigrants] arrive for the first time in the USA, and they see hatred in the North American's face. So in that exact moment they notice that their dreams were untrue and the reality is: "they're rejected in American society." Here, they're not welcome. (Amalia, 18 year-old Ecuadoran)

I feel bad for people that came from other countries. They can't take care of their families because they feel the pressure of this country. They feel like they have to do something. They are not in their country [where] they can say: "I'm free." Even if you have your green card or whatever, that just doesn't matter, you know..... You see most of the people that is Spanish or Latin people is working in the field, is working in hands jobs, as handymans. Not working in offices, not taking the jobs 
that American people have right now because we don't have the skills and we don't have the education. We not taking your jobs. We are helping you with your jobs. (Sergio, 21 year-old Mexican)

The workshop participants were broken up into small groups of three or four and read aloud to their group the selected excerpt provided. Following these readings, the participants came together as a large group and discussed what they had read, which led us into our concluding activity which included a selfreflective summary of what (if anything) in their thinking about immigrant persons and immigration had changed.

\section{Step 6: Reflection}

At the end of the workshop, participants were asked to complete a feedback sheet that required them to reflect and respond to the following questions: 1) If the individuals in the immigrant voices excerpts were here looking at your lists, how do you think they would feel? 2) Are there any items you find to be stereotypes? 3) What words might you add that you didn't the first time?

The participants identified generating the sensory lists as having the most impact on their thinking/beliefs about immigration. They were able to recognize their biases when they were exposed to the raw data, which hung on posters in front of the class throughout the workshops. One student wrote in her reflection responding to question \#1: "The lists made me think the most about immigrants and the average American's perception ... and in many cases prejudice against them. It was the biggest eye-opener."

The participants recognized the negativity in their words, even admitting that the immigrants "would be appalled." "Thank god this is anonymous," one of them wrote. In spite of this, our data does reflect an unwillingness to let go of some of the negative perceptions: "They would be offended, because they are probably (our emphasis) clean (not dirty) people that wouldn't enjoy being compared to the smell of a sock." While the fact that this participant was willing to consider that immigrants are "probably" clean does show progress, it also indicates that much more progress is needed.

The second most influential part of the workshop, as reported by the participants, was reading the voices of young adult immigrants who were the same age as these college students.

As researchers, we realize that it is difficult to separate one part of the workshop from another and examine them separately. The various facets of what we worked on with the participants come together to help generate critical thought. As we mentioned earlier, our workshop format was intentionally revised to create this critical thought. We see each part of the workshop as essential in preparing the preservice teachers to confront their biases, a necessary step in change. As one participant wrote in her reflection: 
I'm sure the authors of these narratives would be outraged if they saw our lists because they are not "dirty, spicy, or different." No one would apply such cruel words to their own families. If we really considered who we were talking about, I would hope our lists would be less offensive. It's very negative to say immigration is "dirty, spicy, bad smelling, unwashed, crazy, strange, sticky, weird, unusual, scary, muggy, sweaty, uncomfortable, and sandy." I would like to add "refreshing, new culture, excitement, and nervousness."

Findings from the reflections written individually at the conclusion of the workshop indicate that the activities had at least started the participants to question their perceptions of immigration. When given the opportunity to add any terms or descriptions to the original lists generated to describe immigration, $30 \%$ of the participants added words that showed empathy for immigrants, choosing to add terms such as hope, excitement, and anxiety to their lists. Additionally, $40 \%$ of the participants stated they would add more accepting descriptors such as human beings and equals. 30\% of the preservice teachers found no fault with their original statements and descriptions and would make no changes.

Other "positive descriptors" that participants included in response to question \#3 were: opportunity, caring, open-minded, hard-working, freedom, positive influence, and community. We found that the new descriptive terms they would add to their original lists fall into two key categories: 1) more empathetic toward immigrants' experiences, acknowledging their challenges and difficulties, or 2) empathetic to the immigrants as individuals using words such as scared, excited, confused.

However, few contributed any words that suggest that immigrants offer positive contributions to the United States. Out of 64 new descriptive words counted, only two (2) included words of positive contributions made by immigrants to our society. Those words were positive influence and offer a new variety.

\section{Discussion}

These findings encourage us to continue this work so that we may examine more deeply the intersections between immigration as historical, social, political, economic, and cultural texts in relationship to the biases, assumptions, or beliefs of beginning educators working with immigrant students. The small moves toward more consciously positive and empathetic attitudes around the immigrant experience are a step in the right direction, yet our findings suggest that we have only opened the door but a crack for these preservice teachers. The results imply that this work must be ongoing and consistent across longer periods of time and across other venues in order to affect deep change. Few people are completely transformed in their world views as the result of a single workshop. But our findings do demonstrate that below the surface of polite dialogue common in classrooms of teacher preparation, somewhere in our senses, and in 
our memories, we each embody hidden biases and assumptions that need to be brought into critical conversations. These conversations should be at the center of any teacher preparation program. We believe that the resolutions to these biased assumptions must similarly be introduced not through "talking at" preservice teachers, or in handing them statistics, but by throwing their bodies and their hearts into experiential processes which reorient the senses toward those of the "Other."

The new generation of future US teachers-the 18-24-year-olds currently pursuing undergraduate studies in Education-has grown up in a country that systematically and habitually ostracizes immigrants. In-service teachers are similarly bombarded with negative perceptions of immigrants. As hooks (1995) reminds us, "representation is a crucial location of struggle for any exploited and oppressed people asserting subjectivity and decolonization of the mind" ( $p .3)$. The anti-immigrant fervor that has gripped the United States for much of the last twenty years has had a persistent presence in our communities and schools. Media portrayals of immigration in the United States overwhelmingly focus on illegal immigration, especially immigrants from Mexico and Central America. Current preservice teachers in the early stages of their careers have been socialized and have learned to communicate amidst the political movements that spawned California's Proposition 187, the anti-bilingual policies of the mid-1990s in California and Arizona, anti-immigrant welfare and immigration reform laws, and recent laws in Arizona, Georgia, and Alabama that target immigrants for incarceration and deportation on questionable constitutional grounds.

These preservice teachers have lived through the September $11^{\text {th }}$ terrorist attacks, and the fear, anxiety, and anti-immigrant fervor that escalated in the wake of the attacks. They have grown up surrounded by negative stereotypes embedded in popular culture. Their social consciousness is developing during a time when small towns without immigrant populations pass English-only laws, when blaming immigrants for a depressed economy is commonplace, when deportation has reached record levels, and when the dramatic increase in the number of people dying at the U.S.-Mexican border as a result of heightened border enforcement is deemed acceptable. We now look to these young adults who grew up during these times to teach the increasing numbers of immigrant and first generation children in our schools.

We suggest that such practices as the ones discussed here must become more integral facets of teacher preparation programs in an effort to promote an anti-racist pedagogy. Educational practices manifested in how we teach as well as what we teach have become central tenets to an imperialist colonial view of the world, one which elevates knowledge of the mind as having privilege over knowledge of the body (or the senses) and subsequently creating a hierarchy of what (and whose) knowledge has value. This hierarchy finds its way across all spaces of teaching and learning, from the Tylerian models for K-12 classroom instruction and the books of Bennett (1995) and Hirsch (1987) that espouse what knowledge is of most value to all children, to the colonial gaze of academic inquiry described by Tuhiwai-Smith (1999) that views indigenous perspectives, 
methodologies, and languages as "naive, contradictory, or illogical" - i.e., not making sense (p. 14).

Using our bodies to provoke critical dialogue can encourage participants towards transformative thinking. Aesthetic ways of making meaning, the use of our senses, form, and hopefully transform preservice teachers' perceptions of "the Other." Aesthetics, as examined in this study, signify "the possibility to transition into another mode of being - the freedom to change situations, to abolish a petrified, or blocked systems of conditioning" (Gablik, 1991, p. 43).

Working our participants away from what they think "they know" toward a critical praxis of the body, the sense, and the emotions, we attempted to disorient them, to move them away from their original culturally influenced, Whitedominant orientation toward perspectives different from their own. Through these engagements with alternative consciousness, participants could use their imagination to call forward the emotions, experiences, and lived moments of immigrants. As one participant wrote in her final reflection, "Performing the skits gave us a visual feel of immigration."

Furthermore, marginalized people are given voice through literature (Fox \& Short, 2003; Hefflin \& Barkesdale-Ladd, 1997), which opens doors for rich, critical discussion about complex issues with students of all ages. Children's books that are written in narrative voice draw readers into the story, allowing them to identify with and relate to the characters, thus building a bridge between theory and personal learning. Reading the voices of young adult immigrants brings that connection much closer to our preservice teachers and evokes empathy beyond what the children's literature alone accomplished. After viewing a difficult topic from a comfortable distance through these varied forms of literature, the preservice teachers began to identify themselves in the issues, which in a way, created a bridge between the theory and the personal (CochranSmith, 1984; Eeds \& Wells, 1989; Sipe, 2000).

The stories told by immigrants confound simplistic assertions of antiimmigrant advocates regarding legal status, labor force participation, and civic engagement (Mogge, 2008). They add complexity to multicultural education practices that are too often shallow and insipid (Nieto, 2000). They help future teachers to move from passive to active stances through which culturally responsive pedagogy can be constructed to challenge and reshape curriculum (Moje \& Hinchman, 2004).

When all three strategies-children's literature, drama, and first-person voices-are interwoven, we believe that language moves from being merely a mode of transmission to a process that embodies the senses to transform not only what we "know" but also what we believe and, most importantly, how we experience the world around us. However, these workshops alone are not sufficient to re-educate beginning teachers to be critically reflective about immigration issues and immigrant children. More work must be done. 


\section{References}

Anderson, T., \& Milbrandt, M. (1998). Authentic instruction in art: How to dump the school art style. Visual Art Research, 24, 13-20.

August, D., \& Shanahan, T. (Eds.). (2008). Developing reading and writing in second-language learners: Lessons from the report of the national literacy panel on language minority children and youth. Washington, DC: Center for Applied Linguistics/International Reading Association.

Ball, A. F., Skerrett, A., \& Martinez, R. A. (2011). Research on diverse students in culturally and linguistically complex language arts classrooms. In Handbook of research on teaching the English language arts (3rd ed., pp. 22-29). New York, NY: Routledge.

Banks, J. (2004). Teaching for social justice, diversity and citizenship in a global world. The Educational Forum, 68, 296-305.

Battiste, M. (2011). Forward: Cognitive imperialism and decolonizing research: Modes of transformation. In C. Reilly, V. Russell, L. Chehayl, \& M. McDermott (Eds.), Surveying borders, boundaries, and contested spaces in curriculum and pedagogy (pp. Xv-xxviii). Charlotte, NC: Information Age Publishing.

Bennett, B. (1995). The children's book of virtues. New York, NY: Simon and Schuster.

Bialystock, E. (1997). Effects of bilingualism and biliteracy on children's emerging concepts of print. Developmental Psychology, 33(3), 429-440.

Boal, A. (2002). Games for actors and non-actors ( $2^{\text {nd }}$ ed.). New York, NY: Routledge.

Boal, A. (1995). The rainbow of desire: The Boal method of theatre and therapy. London, UK: Routledge.

Boal, A. (1979). Theatre of the oppressed. London, UK: Pluto.

Burr, V. (2003). Social constructionism ( $2^{\text {nd }}$ ed.). New York, NY: Routledge.

Carey, R. (1998). Critical art pedagogy: Foundations for a postmodern art education. New York, NY: Garland.

Christensen, L. M. (2009). Teaching for joy and justice: Re-imagining the language arts classroom. Milwaukee, WI: Rethinking Schools.

Cochran-Smith, M. (1984). The making of a reader. Norwood, NJ: Ablex Publishing Corporation.

Copenhaver, J. F. (2000). Silence in the classroom: Learning to talk about issues of race. The Dragon Lode, 18(2), 8-16. 
Creswell, J. (1998). Qualitative inquiry and research design: Choosing among five traditions. Thousand Oaks, CA: Sage.

Cummins, J. (1993). Empowerment through biliteracy. In J. V. Tinajero, \& A. F. Ada (Eds.), The power of two languages: Literacy and biliteracy for Spanish speaking students (pp. 9-25). New York, NY: Macmillan/McGraw Hill.

Eeds, M., \& Wells, M. (1989). Grand conversations: An exploration of meaning construction in literature study groups. Research in the Teaching of English, 23(1), 4-29.

Emerson, R. M., Fretz R. I., \& Shaw, L. L. (1995). Writing ethnographic fieldnotes. Chicago, IL: University of Chicago Press.

Fox, D., \& Short, K. (2003). Stories matter: The complexity of cultural authenticity in children's literature. Urbana, IL: National Council of Teachers of English.

Freire, P. (1970). Pedagogy of the oppressed. New York, NY: Herder and Herder.

Freire, P. (1998). Pedagogy of freedom: Ethics, democracy and civic courage. Oxford, UK: Rowman and Littlefield.

Gablik, S. (1991). The reenchantment of art. New York, NY: Thames and Hudson.

Garcia, E. E., \& Wiese, A. M. (2009). Policy related to issues of diversity and literacy. In L. Mandel Morrow, R. Rueda, \& D. Lapp (Eds.), Handbook of research on diversity and literacy. (pp. 32-53). New York, NY: The Guilford Press.

Gaztambide-Fernandez, R. (2002). (De)Constructing art as a model/ (re)constructing art as a possibility: An interactive essay exploring the possibilities of the arts in relationship to education. In T. Poetter, K. Wilson Baptist, C. Higgins, C. Haerr, \& M. Hayes (Eds.), In(ex)clusion: $(R e) v i s i o n i n g$ the democratic ideal (pp. 83 - 107). Troy, NY: Educator's International Press.

Hakuta, K. (1986). Mirror of language: The debate on bilingualism. New York, NY: Basic Books.

Hefflin, B., \& Barksdale-Ladd, M. (1997). African American children's literature that helps students find themselves: Selection guidelines for grades K-3. The Reading Teacher, 54(8), 810-819.

Hirsch, E. D. (1987). Cultural literacy: What every American needs to know. Vancouver, WA: Vintage Books.

hooks, B (1995). Art on my mind: Visual politics. New York, NY: New Press.

Ignatiev, N. (1995). How the Irish became white. New York, NY: Routledge 
Krashen, S., \& McField, G. (2006). What works? Reviewing the latest evidence on bilingual education. Language Learner, 1(2), 7-10.

Kumashiro, K. (2000). Toward a theory of anti-oppressive education. Review of Educational Research, 70(1), 25-53

Kurtz, J. (2000). Faraway home. (E. B. Lewis, Illus.). New York, NY: Harcourt Brace Publishers.

Laminack, L., \& Wadsworth, R. (2006). Learning under the influence of language and literature: Making the most of read-alouds across the day. Portsmouth, NH: Heinemann.

Leavy, P. (2009). Method meets art: Arts-based research practice. New York, NY: The Guilford Press.

Mogge, S (2008). Confronting intolerance: Critical, responsive literacy instruction with adult immigrants. Rotterdam, Netherlands: Sense Publishers.

Moje, E. B., \& Hinchman, K. (2004). Culturally responsive practices for youth literacy learning. In T. L. Jetton, \& J. A. Dole (Eds.), Adolescent literacy research and practice (pp. 331-350). New York, NY: The Guilford Press.

National clearinghouse for English language acquisition and language instruction education programs. (2008). US Department of Ed. Retrieved from http://www.ncela.gwu.edu/expert/faq/08leps.html

Nieto, S. (2000). Multiculturalism, social justice, and critical teaching. In I. Shore, \& C. Pari (Eds.), Education is politics: Critical teaching across differences, K-12 (pp. 121-130). Portsmouth, NH: Heinemann.

Patton, M.Q. (1980). Qualitative evaluation method. Beverly Hills, CA: Sage.

Pew Research Center for the People and the Press. (2006). No consensus on immigration problem or proposed fixes: America's immigration quandary. Washington, DC: Pew Hispanic Center. Retrieved from http://pewhispanic.org/files/ reports/63/pdf

Rankie Shelton, N., \& McDermott, M. (2008). Reading "others": Literary and societal translations" of cultural diversity and societal equity through children's literature. Presented at the International Reading Association World Congress, Costa Rica, July 2008.

Rankie Shelton, N., \& McDermott, M. (2010). Using literature and drama to understand social justice. Teacher Development, 14(1), 123-135.

Reilly, C. (2011). Introduction: Putting it together. In C. Reilly, V. Russell, L. Chehayl, \& M. McDermott (Eds.), Surveying borders, boundaries, and contested spaces in curriculum and pedagogy (pp. xxix-xxxix). Charlotte, NC: Information Age Publishing.

Sinclair, U. (1906). The jungle. Mineola, NY: Dover Publications. 
Sipe, L. (2000). 'Those two gingerbread boys could be brothers': How children use intertextual connections during storybook readalouds. Children's Literature in Education, 31, 73-90.

Spradley, J. (1980). Participant observation. New York, NY: Harcourt.

Tichenor, D. J. (2002). Dividing lines: The politics of immigration control in America. Princeton, NJ: Princeton University Press.

Thomas, W. P., \& Collier, V. P. (1997). School effectiveness for language minority students. National Clearinghouse for English Language Acquisition (NCELA) Resource Collection Series, No. 9.

Tuhiwai-Smith, L. (1999). Decolonizing methodologies: Research and indigenous peoples. London, UK: Zed Books.

U.S. Census Bureau (September 2011). "The 2012 Statistical Abstract." Retrieved from http://www.census.gov/compendia/statab/cats/population/ native_and_foreign-born_populations.html

Valdez, V. E., \& Callahan, R. M. (2011). Who is learning language(s) in today's schools? In D. Lapp,\& D. Fisher (Eds.), Handbook of research on teaching the English language arts ( $3^{\text {rd }}$ ed.). New York, NY: Routledge.

Wightman, J. (2010). ELL education in Arizona: Unconstitutional segregation or just inappropriate. Texas Hispanic journal of law and policy, 16(121), 121152.

Wiley, T. G. (2005). Literacy and language diversity in the United States (2nd ed.). Washington, DC: Center for Applied Linguistics.

Wolk, S. (2004). Using picture books to teach for democracy. Language Arts, 82, 26-35.

Worthman, C. (2002). Just playing the part: Engaging adolescents in drama and literacy. New York, NY: Teachers College Press.

Zolberg, A.R. (2006) A nation by design: Immigration policy in the fashioning of America. Cambridge, MA: Harvard University Press. 


\section{Appendix 1. Description of the six-step workshop}

1. Two minute writing prompt with these questions:

- What do you know about immigration?

- What do you believe about immigration?

- What is positive?

- What is negative?

2. In small groups we asked participants to generate lists, each written on large poster paper: What does immigration look like, smell like, feel like, taste like and sound like?

3. We read aloud one children's book (Kurtz, 2000): Book has a positive immigration theme. Discuss our connections and reaction to the book.

4. Drama activities (using Boal's's Theater of the Oppressed techniques [1979]):

- Tableaux representing these concepts:

home/family/discrimination/isolation Participants worked in groups to present one of these terms to then be discussed with the whole group, analyzing what they "saw" in each.

- Playback re-enacting stories of personal experiences with immigration.

Participants each shared a story of personal experience having to do with immigration. In small groups they selected one of the stories to "act out." Following a critical discussion including questions such as, "Who has the power in this situation" participants were asked to "play back" the scene altering the existing power dynamics. Follow up a whole-group discussion.

5. Voices from young adult immigrant students: Students read excerpts of written and spoken messages from immigrant students (Author 3, 2008) and discuss their thoughts and reactions to these stories first in small group, then share with the larger group.

6. Reflections: Students respond in writing to guided questions about their how their thoughts on the immigrant experience may have changed:

- If the individuals in the narratives were here looking at the lists constructed in the beginning how do you think they would respond or feel?

- Are there any items that you find to be negative stereotypes? List them. 
- What words might you add that you didn't the first time?

- What part of this workshop had the most impact on your thinking/beliefs about immigration? Explain. 